\title{
PENGARUH KONFLIK INTERPERSONAL, BEBAN KERJA TERHADAP STRES KERJA PADA PEGAWAI DI DINAS PERHUBUNGAN PROVINSI BALI
}

\author{
Putu Yogi Agastya Pratama ${ }^{1}$ \\ IGB Honor Satrya ${ }^{2}$
}

${ }^{1,2}$ Fakultas Ekonomi dan Bisnis Universitas Udayana (Unud), Bali, Indonesia e-mail: putuyogiagastyapratama15@gmail.com

\begin{abstract}
ABSTRAK
Penelitian ini bertujuan untuk mengetahui pengaruh konflik interpersonal dan beban kejra terhadap stress kerja pada pegawai di Dinas Perhubungan Provinsi Bali. Konflik Interpersonal perlu diperhatikan untuk menghilangkan perbedaan pendapat antara individu dengan individu lainnya. Penelitian ini dilakukan pada seluruh pegawai yang ada di Dinas Perhubungan Provinsi Bali. Sampel yang diambil adalah sebanyak 94 Pegawai. Pengumpulan data dilakukan dengan penyebaran kuisioner dengan menggunakan skala likert 5 point untuk mengukur 15 item pernyataan. Teknik analisis yang digunakan adalah analisis Regresi. Hasil penelitian ini menunjukkan bahwa Konflik Interpersonal berpengaruh positif dan signifikan terhadap Stres Kerja dan Beban Kerja berpengaruh positif dan signifikan terhadap Stres Kerja di Dinas Perhubungan Provinsi Bali. Manajer perusahaan harus menjaga dan selalu memperhatikan seberapa besar Stres Kerja yang dirasakan oleh karyawannya. Hal ini bertujuan agar dapat menciptakan karyawan yang memiliki sikap peran penting dalam rangka mendukung tercapainya kinerja yang baik sesuai dengan tujuan instansi terkait di Dinas Perhubungan Provinsi Bali.
\end{abstract}

Kata Kunci: konflik interpersonal, beban kerja, stres kerja

\section{ABSTRACT}

This study aims to determine the influence of interpersonal conflict and the severe expenses against job stress on the employees at the Transportation Department of Bali Province. Interpersonal conflicts need to be considered to eliminate differences of opinion between individuals and other individuals. This research was conducted on all employees in Bali Transportation Department. The sample is 94 employees. The data was collected by distributing questionnaires using a 5-point likert scale to measure 15 statement items. The analysis technique used is Regression analysis. The results of this study indicate that Interpersonal Conflicts have a positive and significant effect on Work Stress and Workload has a positive and significant effect on Work Stress in Bali Provincial Transportation Department. Company managers must maintain and always pay attention to how much Job Stress is felt by employees. It aims to create employees who have important role attitudes in order to support the achievement of good performance in accordance with the objectives of relevant agencies in Bali Provincial Transportation Department.

Keywords: interpersonal conflict, workload, working stress 


\section{PENDAHULUAN}

Sumber daya manusia (SDM) merupakan faktor utama dalam mencapai tujuan perusahaan. Pencapaian tujuan perusahaan tidak lepas dari manusia yang berperan aktif dan dominan setiap kegiatan organisasi, karena manusia sebagai perencana, pelaku, serta penentu terwujudnya tujuan perusahaan. Sumber daya manusia dalam perusahaan perlu adanya pengelolaan secara profesional agar terwujud keseimbangan antara kebutuhan karyawan dengan tuntutan dan kemampuan perusahaan. Manajemen sumber daya manusia juga dapat didefinisikan pula sebagai suatu pengelolaan dan pendayagunaan sumber daya yang ada pada individu (pegawai). Untuk dapat mengelola SDM dengan baik, setiap pemimpin dan manajer serta bagian yang menangani SDM harus mengerti masalah manajemen SDM dengan baik pula (Widodo, 2015).

Stres sebagai suatu kondisi dinamis dimana individu dihadapkan pada kesempatan, hambatan dan keinginan dan hasil yang diperoleh sangatlah penting tetapi tidak dapat dipastikan. Siagian (2010) menyatakan sumber stres dapat digolongkan pada yang berasal dari pekerjaan dan dari luar pekerjaan seseorang. Pendekatan stres kerja dilakukan untuk mengatasi kendala yang dihadapi karyawan saat bekerja. Bagi individu penting dilakukannya penanggulangan stres kerja karena stres dapat mempengaruhi kehidupan, kesehatan dan produktivitas. Bagi perusahaan pengaruh terhadap kinerja dan efektivitas dari perusahaan. Kehidupan modern yang semakin kompleks, manusia akan cenderung mengalami stres apabila ia kurang mampu mengadaptasikan keinginan dengan kenyataan yang ada, baik kenyataan yang ada di dalam maupun diluar dirinya. Segala 
Putu Yogi Agastya Pratama, Pengaruh Konflik Interpersonal dan Beban Kerja terhadap...

macam bentuk stres pada dasarnya disebabkan oleh kurang pengertian manusia akan keterbatasannya diri sendiri (Noviansyah, 2011:45). Ketidakmampuan untuk melawan keterbatasan inilah yang akan menimbulkan frustrasi, konflik, gelisah, dan rasa bersalah yang merupakan tipe-tipe dasar stres (Luthan, 2006:439). Stres di tempat kerja akhir-akhir ini telah menjadi masalah yang lebih serius bagi manajemen perusahaan di dalam dunia bisnis (Qureshi et al., 2013:32). Karyawan sering dihadapkan dengan berbagai masalah dalam perusahaan sehingga sangat mungkin terkena stres. Paille (2011) menyatakan bahwa stress kerja mampu menurunkan kondisi fisik seseorang di tempat kerja, meningkatkan tekanan psikologis di tempat kerja, dan menyebabkan kelelahan yang berlebihan.

Stafylal et al. (2013:91) menyatakan bahwa faktor eksogen dari stres kerja yaitu kendala organisasi dan konflik interpersonal. Menurut (Sliter et al., 2011:424), konflik interpersonal dalam kerangka kerja yang mempengaruhi perilaku karyawan baik antara mereka sendiri ataupun dalam hubungannya dengan pelanggan mereka. Selain itu konflik interpersonal berhubungan dengan efek samping dalam konteks kerja. Karakteristik kepribadian dan dukungan sosial, menyerap ketegangan emosional yang timbul dari konflik (Ilies et al., 2011:44). Stafylal et al. (2013:91) menunjukan bahwa perempuan lebih tinggi tingkat stres dibandingkan dengan laki-laki terkait dengan konflik interpersonal. Dimana tingkatan emosional perempuan lebih tinggi dari pada laki-laki maka dari itu konflik sering dialami oleh perempuan. Penelitian Restiaty (2006), dengan kelelahan kerja yang merupakan gejala fisik stres kerja, artinya semakin berat beban kerja di tempat kerja maka semakin tinggi tingkat stres kerja. 
Stres biasanya dilihat sebagai hasil dari beban kerja yang tinggi, hubungan antara konstruksi yang sangat kompleks Gunov et al. (2011). Stressor di tempat kerja bisa berwujud fisik maupun psikis, yang semuanya bisa menimbulkan stres kerja bagi karyawan. Stres dapat menjadi pemacu semangat seseorang untuk bekerja, akan tetapi dalam kadar tertentu stres dapat pula menjadi pemicu timbulnya lesu kerja, penurunan kondisi fisik dan mental yang akhirnya dapat mempengaruhi semangat seorang karyawan dalam bekerja, yang akhirnya juga berpengaruh terhadap kinerja karyawan (Handoko, 2001).

Masalah-masalah yang dihadapi Dinas Perhubungan Provinsi Bali yaitu di bidang-bidang yang berhubungan dengan masyarakat, yang mencakup angkutan jalan, bidang lalu lintas, bidang pelayaran, bidang keterpaduan moda, UPT. Perlengkapan jalan, UPT. Sarbagita, UPT. Pusdal LLAJ (Lalu Lintas Angkutan Jalan). Petugas dan pegawai sering mengalami tingkat stress dalam pekerjaannya pada bidang tersebut. Dari hasil pra-research dengan petugas LLAJ menyatakan bahwa permasalahan di Bidang angkutan jalan biasannya masalah yang muncul diantaranya penyimpangan cara pelayanan angkutan seperti tidak sesuainya beban angkut yang sudah ditentukan oleh kendaraan. Bidang lalu lintas angkutan ini memfasilitasi beban angkutan orang, barang dan sewa yang sudah sesuai dengan kapasitas. Dengan adanya permasalahan dalam pelanggaran angkutan tersebut menyebabkan petugas lalu lintas angkutan berinteraksi negatif dengan oknum yang melanggar peraturan pengangkutan barang. Bidang pelayaran ini mengatasi melayani pelayanan angkutan laut seperti angkutan pelayaran yang membatasi angkutan untuk melebihi beban angkut, permasalahan yang dihadapi petugas 
Putu Yogi Agastya Pratama, Pengaruh Konflik Interpersonal dan Beban Kerja terhadap...

pelayanan angkutan laut ini muatan yang berlebih sehingga menyebabkan ketidakamanan pelayaran. Bidang keterpaduan moda ini menentukan arah dan tujuan angkutan transportasi.

UPT perlengkapan jalan diantaranya memfasilitasi kapasitas keselamatan jalan agar jalan tersebut mudah dan aman dilalui oleh pengguna kendaraan tersebut, permasalahan yang dihadapi tersebut masyarakat sering melanggar rambu yang mengakibatkan fasilitas perlengkapan tidak berfungsi dengan baik karena pelanggaran rambu. UPT. Sarbagita tujuannya untuk mengurangi kemacetan karena mempermudah kendaraan yang ada di jalan. Permasalahan yang dihadapi ialah sarbagita tidak tepat dan waktu yang di tentukan. UPT pusdal LLAJ ini mengatasi rambu lalu litas sehingga pengedara jalan tidak mudah terkena kemacetan. Permasalahan yang dihadapi adalah apabila kurangnya kordinasi petugas lapangan dan petugas dalam yang menyebabkan penanganan dilapangan tidak teratasi dengan baik. bidang-bidang tersebut memiliki tingkat stres kerja yang dialami pegawai Dinas Perhubungan Provinsi Bali. Tingkat stress yang sering dialami oleh bidang-bidang yangberhubungan dengan masyarakat yang sering mengalami stres kerja.

Stres kerja yang dialami oleh pegawai tersebut dikarenakan adanya permasalahan pekerjaan yang tidak terkoordinasi dengan baik terhadap masyrakat, pegawai antar divisi dan oknum pelanggar peraturan yang akan menimbulkan konflik dan beban kerja antar pegawai, bisa jadi juga dikarenakan adanya permasalahan ditempat kerja yang dikarenakan pekerjaan yang berlebihan dan dengan tidak sesuai hasil yang didapatkannya. Dalam pekerjaan pasti ada 
ketidakcocokan pendapat antara pegawai dalam menjalankan organisasi yang sesuai didalam pekerjaan, maka dari itulah stres kerja yang dirasakan oleh pegawai Dinas Perhubungan Provinsi Bali.

Stres sebagai suatu kondisi dinamis dimana individu dihadapkan pada kesempatan hambatan dan keinginan dan hasil yang diperoleh sangatlah penting tetapi tidak dapat dipastikan. Siagian (2010) juga berpendapat bahwa, sumber stres dapat digolongkan pada yang berasal dari pekerjaan dan dari luar pekerjaan seseorang. Pendekatan stres kerja dilakukan untuk mengatasi kendala yang dihadapi karyawan saat bekerja. Bagi individu penting dilakukannya penanggulangan stres kerja karena stres dapat mempengaruhi kehidupan, kesehatan dan produktivitas. Bagi perusahaan pengaruh terhadap kinerja dan efektivitas dari perusahaan. Kehidupan moderen yang semakin kompleks, manusia akan cenderung mengalami stres apabila kurang mampu mengadaptasikan keinginan dengan kenyataan yang ada, baik kenyataan yang ada didalam maupun diluar dirinya.

Konflik interpersonal telah didefinisikan secara luas sebagai persepsi yang terjadi ketika pihak yang berbeda terus berbeda pandangan atau konflik ketika adanya ketidakcocokan antar individu satu dengan yang lainnya (Hung et al., 2013:141).

Rivai (2013) Konflik yaitu pertentangan dalam hubungan kemanusiaan (intrapersonal atau interpersonal) antara satu pihak dengan pihak lain dalam mencapai suatu tujuan, yang timbul akibat adanya perbedaan kepentingan, emosi atau psikologi dan nilai. Konflik dapat menjadi energi yang kuat apabila dapat 
Putu Yogi Agastya Pratama, Pengaruh Konflik Interpersonal dan Beban Kerja terhadap...

dikelola dengan baik sehingga dapat dijadikan motivasi, jika konflik tidak dapat dikendalikan mengakibatkan kinerja organisasi rendah. Penyebab terjadinya konflik pada setiap organisasi sangat bervariasi, bergantung pada cara-cara individu menafsirkan, mempersepsi, dan memberikan tanggapan.

Dhania (2010:15) menyatakan beban kerja adalah sekumpulan atau sejumlah kegiatan yang harus diselesaikan oleh suatu unit organisasi atau pemegang jabatan dalam jangka waktu tertentu. Beban kerja dapat dibedakan lebih lanjut ke dalam beban kerja berlebihan atau terlalu sedikit (kuantitatif). Beban kerja ini timbul sebagai akibat dari tugas-tugas yang terlalu banyak atau sedikit diberikan kepada tenaga kerja untuk diselesaikan dalam waktu tertentu. Beban kerja berlebihan atau terlalu sedikit (kualitatif) yaitu jika orang merasa tidak mampu untuk melakukan suatu tugas, atau tugas tidak menggunakan ketrampilan atau potensi dari tenaga kerja. Disamping itu beban kerja berlebihan kuantitatif dan kualitatif dapat menimbulkan kebutuhan untuk Stres biasanya dilihat sebagai hasil dari beban kerja yang tinggi, hubungan antara konstruksi ini kompleks (Gunov et al., 2011:771).

Permasalahan yang ada dalam urusan pemerintahan, dalam menanganinya dibutuhkan pemikiran dari pegawai yang tenang, agar waktu penyelesaian tugas yang cukup dan hubungan antara pegawai yang terjalin menjadi baik. Stres kerja yang dialami oleh pegawai dapat disebabkan oleh tuntutan yang tinggi dari pekerjaan mereka. Fakta yang tak terbantahkan bahwa semua pekerjaan membuat stres bagi karyawan dalam tingkat yang berbeda, stres yang dapat menyebabkan perubahan fungsi alami organisme dan memiliki konsekuensi untuk kesehatan 
seseorang (Stafylal et al., 2013:91). Stres di tempat kerja biasanya terjadi ada masalah utama yang kekhawatirannya tidak hanya dirasakan oleh karyawan tetapi juga organisasi dan masyarakat pada umumnya. Stres kerja akan muncul apabila di suatu titik karyawan merasa tidak dapat lagi memenuhi tuntutan-tuntutan pekerjaan. Karyawan yang tidak dapat menahan stress kerja dalam jangka panjang akan membuat karyawan tersebut tidak akan mampu lagi bekerja di perusahaan tersebut. Manurung \& Ratnawati (2012:145) pada tahap yang semakin parah, stress bisa membuat karyawan menjadi terbebani dengan keadaan atau bahkan akan niat untuk mengundurkan diri (Turnover). Saat karyawan meninggalkan perusahaan, kemampuan karyawan lainnya untuk menyelesaikan pekerjaan yang ada akan terganggu (Fah et al., 2010:57). Sangat penting bagi perusahaan untuk mengidentifikasi sejak dini hal-hal yang menyebabkan karyawan memiliki keinginan untuk berpindah kerja. Maka dari ini keinginan untuk berpindah kerja (turnover intention) merupakan hal yang sangat seriusdalam konteks sumber daya manusia dalam perusahaan (Fah et al., 2010:57).

Pemerintah Provinsi Bali juga membagi organisasinya ini menjadi beberapa Satuan Kerja Perangkat Daerah (SKPD), salah satunya adalah Dinas Perhubungan Provinsi Bali, yang beralamat di jalan Kapten Cok Agung Tresna I No. 1 Denpasar merupakan pusat dari kegiatan organisasi Pemerintah Provinsi Bali yang memiliki tugas mengurus transportasi darat, udara dan laut serta tugas-tugas lainnya. Dinas Perhubungan Provinsi Bali sama halnya dengan organisasi lain merupakan kumpulan orang-orang dengan berbagai karakter yang tidak bisa dimengerti secara mendalam dan detail dengan berbagai tingkat dan kepentingan, 
Putu Yogi Agastya Pratama, Pengaruh Konflik Interpersonal dan Beban Kerja terhadap...

keinginan, pandangan maupun karakter yang beraneka ragam sering mengundang berbagai konflik dalam berbagai bentuk dan corak kalau tidak dapat dimengerti dan dipahami secara professional akan berdampak pada kinerja dari masingmasing pegawai yang selanjutnya akan berdampak pula pada kinerja organisasi secara keseluruhan, sehingga tujuan dari organisasi tidak tercapai secara optimal.

Dinas Perhubungan Provinsi Bali merupakan Dinas yang memiliki satu Kepala Kepegawaian yang disana memiliki tugas untuk mengetahui SDM para pegawai pada saat menerima pegawai dan pada saat pegawai bekerja sesuai bidang dan tugas masing-masing pekerjaannya, sehingga tugas tersebut berjalan dengan baik.

Dinas Perhubungan Provinsi Bali, memang benar terdapat permasalahanpermasalahan yang dialami oleh pegawai dalam menjalankan pekerjaannya yang menimbulkan stres. Permasalahan tersebut dikarenakan kurang baiknya komunikasi antara pegawai satu dengan yang lainnya sehingga menyebabkan perbedaan pendapat antar individu. Perbedaan pemikiran antara pegawai pun sering terjadi karena latar belakang kebudayaan yang berbeda mengingat jumlah Pegawai Negeri Sipil (PNS) di Dinas Perhubungan Provinsi Bali yang cukup banyak. Beban kerja yang diberikan kepada pegawai pun cukup banyak, sehingga waktu yang diberikan untuk menyelesaikan tugas mereka dirasa kurang cukup oleh pegawai.

Berdasarkan latar belakang yang telah diuraikan, maka yang menjadi tujuan dari penelitian ini adalah untuk mengetahui pengaruh variabel konflik interpersonal terhadap stres kerja pada pegawai Dinas Perhubungan Provinsi Bali, 
dan untuk mengetahui pengaruh variabel beban kerja terhadap stres kerja pada pegawai Dinas Perhubungan Provinsi Bali.

Teori Herzberg membagi situasi yang mempengaruhi sikap seseorang terhadap pekerjaannya menjadi dua kelompok, yaitu : motivator faktor dan dissatisfer (hygiene factors). Motivator Faktor adalah situasi yang membuktikannya sebagai sumber kepuasan kerja, yang terdiri dari : Achievement (Keberasilan dalam menyelesaikan tugas), Recognition (penghargaan), Work it self (pekerjaan itu sendiri), Responbility (tanggung jawab), Possibility of growth (kemungkinan untuk mengembangkan diri), Advancement (kesempatan untuk maju). Sedangkan dissatisfer (hygiene factors) adalah faktor-faktor yang terbukti menjadi sumber ketidakpuasan yang terdiri dari company policy and administration (kebijakan perusahaan dan administrasi), supervision (Supervisi), technical salary (Gaji Teknis), interpersonal (Interpersonal), relation (relasi), working condition (kondisi kerja), job security and status (Keamanan Bekerja dan status).

Stress kerja mampu menurunkan kondisi fisik seseorang di tempat kerja, meningkatkan tekanan psikologis di tempat kerja, dan menyebabkan kelelahan yang berlebihan (Paille, 2011). Stres biasanya dilihat sebagai hasil dari beban kerja yang tinggi, hubungan antara konstruksi ini kompleks (Gunov et al., 2011:771). Robbins (2008), menyatakan bahwa stres sebagai suatu ketidakseimbangan antara keinginan dan kemampuan memenuhinya sehingga menimbulkan konsekuensi penting bagi dirinya. Berbagai definisi mengenai stres telah dikemukakan oleh para ahli dengan versinya masing-masing, walaupun pada dasarnya antara satu definisi dengan definisi lainnya terdapat inti 
Putu Yogi Agastya Pratama, Pengaruh Konflik Interpersonal dan Beban Kerja terhadap...

persamaannya. Stres kerja dapat diartikan sebagai perasaan yang tidak menyenangkan yang menimbulkan ketegangan dan rasa gelisah karena tugastugas atau situasi yang ada di tempat kerja. Indikator stress kerja menurut (Rivai dan Jauvani, 2009:108) adalah sebagai berikut, 1) Stres kerja cendrung membuat kinerja menurun menyelesaikan tugas. 2) Kinerja tidak akan optimal jika mengalami tekanan yang berat dalam bekerja. 3) Stres kerja cenderung dalam bekerja karena tidak harmonis dengan rekan kerja. 4) informasi yang kurang jelas mengenai pekerjaan dari atasan. 5) Stres kerja yang membuat rekan kerja tidak mendapatkan kerjaan.

Konflik interpersonal merupaka konflik yang berkaitan dengan perselisihan antara dua orang anggota organisasi dan terjadi karena adanya perbedaan individual atau pun keterbatasan sumber daya dan ketidaksesuaian tindakan antara pihak yang berhubungan (Dwijanti, 2000). Dana (2006), menyatakan bahwa konflik interpersonal merupakan konflik yang paling sederhana dan merupakan jenis konflik yang paling umum dijumpai ditempat kerja. Salah satu sifat dari konflik interpersonal adalah perlu diperhatikannya hasil-hasil bersama kedua belah pihak maupun hasil-hasil individual masing-masing pihak yang terlibat dalam konflik yang bersangkutan (Winardi, 2004). Suprihanto (2003), menjelaskan bahwa konflik interpersonal terjadi jika antara seseorang dengan orang lain secara individual berada dalam ketidaksesuaian. Lebih lanjut Suprihanto (2003), juga mengatakan bahwa konflik interpersonal ini bisa terjadi di dalam kelompok maupun antara individu dari kelompok atau dengan individu anggota kelompok lainnya. faktor penyebab terjadinya konflik menurut Supardi dan Anwar (2011) adalah sebagai berikut: 1) Perbedaan pendapat antar individu 
merupakan intensitas perbedaan pendapat antar pegawai dalam organisasi. Indikator ini diukur dari responden sering berbeda pendapat dengan rekan kerja pegawai di dalam menjalankan pekerjaannya. 2) Perbedaan pemikiran karena latar belakang kebudayaan yang berbeda merupakan perbedaan individu dengan individu lainnya didalam organisasi. indikator ini diambil dari responden yang mengalami kesulitan bekerja dalam menyatukan pikiran dengan rekan kerja yang berbeda budaya. 3) Perbedaan kepentingan antar individu merupaakan tingkat kepentingan pegawai dalam organisasi untuk menyelesaikan tugasnya. Indikator ini diukur dari konflik yang didapat dihindari walaupun adanya kepentingan antar pegawai. 4) Perbedaan kepribadian tekanan diri sendiri merupakan tekanan diri sendiri yang dialami dalam bekerja.Indikator ini diukur dari konflik yang didapat dalam diri sendiri walaupun adanya perbedaan antar pegawai. 5) Perbedaan kesalahan diri sendiri merupakan kesalahan diri yang dilakukan didalam bekerja.Indikator ini diukur dari konflik yang didapat dalam kesalahan diri sendiri dalam bekerja.

Beban kerja adalah sekumpulan atau sejumlah kegiatan yang harus diselesaikan oleh suatu unit organisasi atau pemegang jabatan dalam jangka waktu tertentu (Dhania, 2010:15). Pengertian beban kerja lainnya yaitu menurut Munandar (2001) beban kerja adalah suatu kondisi dari pekerjaan dengan uraian tugasnya yang harus diselesaikan pada batas waktu tertentu. Dari beberapa pengertian mengenai beban kerja dapat ditarik kesimpulan beban kerja adalah sejumlah kegiatan yang membutuhkan proses mental atau kemampuan yang harus diselesaikan dalam jangka waktu tertentu, baik dalam bentuk fisik maupun psikis. 
Putu Yogi Agastya Pratama, Pengaruh Konflik Interpersonal dan Beban Kerja terhadap...

Faktor yang mempengaruhi beban kerja dalam penelitian Hariyono dkk. (2009:162) adalah sebagai berikut : 1) menangani pekerjaan dengan baik indikator ini diukur dari tanggapan responden yang menyelesaikan tugas dengan waktu yang diberikan. 2) Penerimaan informasi sesuai target indikator ini diukur dari tanggapan responden yang menerima informasi secara layak. 3) Mengambil keputusan dalam bekerja indikator ini diukur dari tanggapan responden mengambil keputusan yang secara layak didalam pekerjaan. 4) waktu dalam menyelesaikan tugas ini diukur dari tanggapan responden yang bekerja sesuai dengan lingkungan pekerjaan yang sudah dikuasai. 5) Standar kerja yang sesuai indikator ini diukur dari tanggapan responden mengambil keputusan yang secara layak didalam pekerjaan.

\section{Hubungan antara konflik interpersonal dengan stres kerja}

Stafyla et al. (2013:91) dalam penelitian mereka mengenai 85 manajer di Slovenia, menemukan bahwa manajer perempuan memiliki tingkat stres yang lebih tinggi dan gejala kecemasan yang lebih parah dibandingkan dengan laki-laki terkait dengan konflik interpersonal dengan kendala organisasi.

Penelitian Agagiotou (2011) yang mempelajari pengaruh konflik interpersonal terhadap stres kerja, komitmen kerja dan kecerdasan emosional sosial pekerja menemukan bahwa pekerja sosial perempuan menunjukan tingkat kecemasan yang lebih tinggi dibandingkan laki-laki. Penelitian (Stafylal et al., 2013:91) menunjukan bahwa perempuan lebih tinggi tingkat stres dibandingkan dengan laki-laki terkait dengan konflik interpersonal. Berdasarkan pemahaman dan hasil penelitian tersebut dapat dikemukakan hipotesis sebagai berikut : 
$\mathrm{H}_{1}$ : konflik interpersonal berpengaruh positif dan signifikan terhadap stres kerja

\section{Hubungan antara beban kerja dengan stres kerja}

Penelitian (Haryanti dan Purwaningsih, 2013:48) yang dilakukan pada perawat instalasi unit gawat darurat di RSUD kabupaten Semarang menunjukan bahwa hubungan antara beban kerja dengan stres kerja memiliki hubungan dalam kategori kuat. Arah hubungan adalah positif, artinya semakin meningkat beban kerja akan semakin menyebabkan stres. Hasil penelitian ini sesuai dengan hasil penelitian yang dilakukan oleh Mahwidhi (2010) tentang pengaruh beban kerja terhadap stres kerja didapatkan hasil bahwa terdapat pengaruh beban kerja fisik (subyektif) dan beban kerja mental (subyektif) terhadap stres kerja.

Penelitian tentang stres perawat IGD yang dilakukan di Malaysia oleh (Lexshimi et al., 2007:146) hasilnya menunjukan bahwa mereka mengalami keluhan sakit kepala, nyeri dada, nyeri perut, bahkan ada yang menyampaikan kehilangan libido. Dari responden didapatkan bahwa yang menyebabkan mereka stres diantaranya adalah: beban bekerja dengan alat canggih yang sangat menegangkan, adanya ketidaknyamanan bekerjasama dengan staf lain dan kurangnya pengalaman bekerja di ruang IGD.

Penelitian (Restiaty, 2006) dengan kelelahan kerja yang merupakan gejala fisik stres kerja, artinya semakin berat beban kerja di tempat kerja maka semakin tinggi tingkat stres kerja. Lebih lanjut dijelaskan bahwa variabel yang berhubungan dengan beban kerja adalah tempat bekerja, jenis pekerjaan, serta beban mental. Tentang beban kerja dan perasaan kelelahan menyimpulkan adanya 
Putu Yogi Agastya Pratama, Pengaruh Konflik Interpersonal dan Beban Kerja terhadap...

hubungan beban kerja ditempat kerja. Berdasarkan pemahaman dan hasil penelitian tersebut dapat dikemukakan hipotesis sebagai berikut :

$\mathrm{H}_{2}$ : beban kerja berpengaruh positif dansignifikan terhadap stres kerja

Berdasarkan tinjauan teori dan hasil penelitian sebelumnya maka model penelitian dapat digambarkan sebagai berikut :

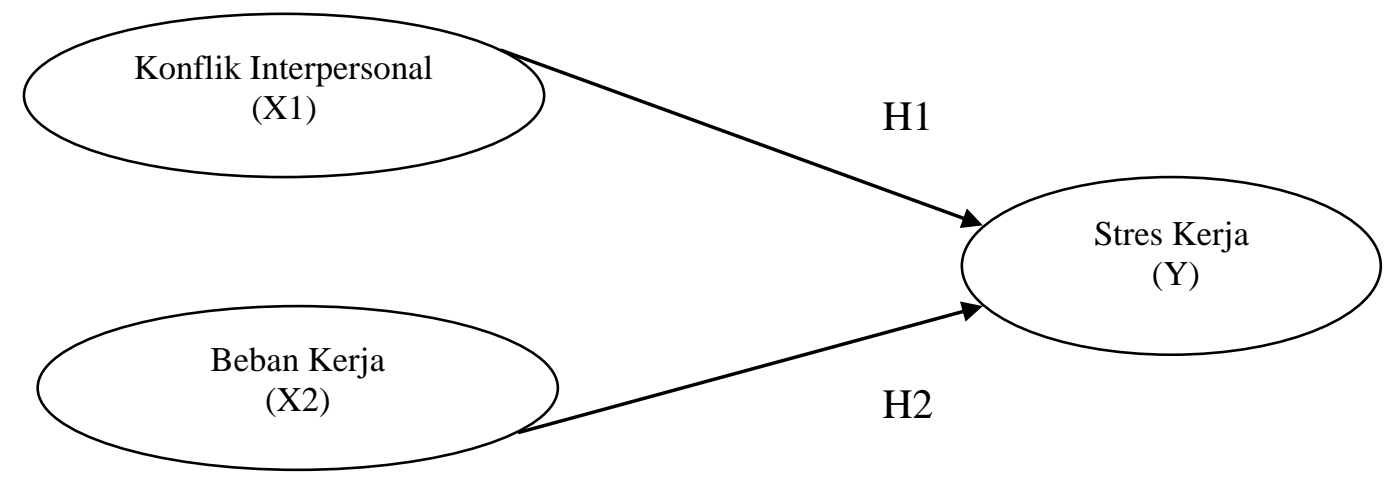

\section{Gambar 1. Model Kerangka Berfikir}

Sumber: Konsep yang dikembangkan dalam penelitian ini, 2018

\section{METODE PENELITIAN}

Berdasarkan permasalahan yang diteliti, penelitian ini digolongkan ke dalam penelitian asosiatif (pengaruh) yaitu meneliti pengaruh konflik interpersonal dan beban kerja terhadap stres kerja pegawai. Data yang di peroleh dalam penelitian ini akan diolah dan dianalisis serta di dukung dengan teori pustaka agar dapat membuktikan hipotesis dan menjawab rumusan masalah rumusan masalah yang sudah dibuat sebelumnya.

Lokasi penelitian dilakukan di Dinas Perhubungan Provinsi Bali yang beralamat di Jalan Cok Agung Tresna I No.1 Denpasar. Alasan peneliti 
melakukan penelitian pada pegawai Dinas Perhubungan Provinsi Bali yaitu karena di temukannya masalah yang terkait dengan stres kerja, konflik interpersonal dan beban kerja pada pegawai Dinas Perhubungan Provinsi Bali. Selain itu pemilihan lokasi ini didasarkan adanya narasumber dan data yang cukup yang mampu diolah oleh peneliti.

Variabel yang digunakan dalam penelitian ini diuraikan dalam Tabel 1.

Tabel 1.

\section{Identifikasi Variabel}

\begin{tabular}{|c|c|c|}
\hline VARIA & DEFINISI & INDIKATOR VARIABEL \\
\hline $\begin{array}{c}\text { Konflik } \\
\text { Interpersonal } \\
\left(\mathrm{X}_{1}\right)\end{array}$ & $\begin{array}{l}\text { Konflik yang berkaitan dengan } \\
\text { perselisihan antara dua orang } \\
\text { anggota organisasi dan terjadi } \\
\text { karena adanya perbedaan } \\
\text { individual atau pun keterbatasan } \\
\text { sumber daya dan } \\
\text { ketidaksesuaian tindakan antara } \\
\text { pihak yang berhubungan }\end{array}$ & $\begin{array}{l}\text { 1) Perbedaan pendapat antar individu. } \\
\text { 2) Perbedaan pemikiran karena latar } \\
\text { belakang kebudayaan yang berbeda. } \\
\text { 3) Perbedaan kepentingan antar } \\
\text { individu. } \\
\text { 4) Perbedaan kepribadian tekanan diri } \\
\text { sendiri. } \\
\text { 5) Perbedaan kesalahan diri sendiri. }\end{array}$ \\
\hline $\begin{array}{l}\text { Beban Kerja } \\
\quad\left(\mathrm{X}_{2}\right) \\
\text { Hariyono, } \\
(2009: 162)\end{array}$ & $\begin{array}{l}\text { Beban kerja adalah sekumpulan } \\
\text { atau sejumlah kegiatan yang } \\
\text { harus diselesaikan oleh suatu unit } \\
\text { organisasi atau pemegang jabatan } \\
\text { dalam jangka waktu tertentu }\end{array}$ & $\begin{array}{l}\text { 1) Menangani pekerjaan dengan baik. } \\
\text { 2) Penerimaan informasi sesuai target. } \\
\text { 3) Mengambil keputusan dalam } \\
\text { bekerja. } \\
\text { 4) Waktu dalam meneyelesaikan tugas. } \\
\text { 5) Standar kerja yang sesuai. }\end{array}$ \\
\hline $\begin{array}{l}\text { Rivai dan } \\
\text { Jauvani, } \\
(2009: 108)\end{array}$ & $\begin{array}{l}\text { Stres kerja memiliki dampak } \\
\text { ketegangan fisik dan pikiran yang } \\
\text { mengakibatkan terjadinya kondisi } \\
\text { yang tidak seimbang dan } \\
\text { mempengaruhi kinerja karyawan }\end{array}$ & $\begin{array}{l}\text { 1) Stres kerja cendrung membuat kinerja } \\
\text { menurun menyelesaikan tugas. } \\
\text { 2) Kinerja tidak akan optimal jika } \\
\text { mengalami tekanan yang berat dalam } \\
\text { bekerja. } \\
\text { 3) Stres kerja karena tidak harmonis } \\
\text { dengan rekan kerja. } \\
\text { 4) informasi yang kurang jelas } \\
\text { mengenai pekerjaan dari atasan. } \\
\text { 5) Stres kerja yang membuat rekan kerja } \\
\text { tidak mendapatkan kerjaan }\end{array}$ \\
\hline
\end{tabular}

Populasi adalah wilayah generalisasi yang terdiri atas obyek atau subyek yang mempunyai kualitas dan karakteristik tertentu yang ditetapkan oleh peneliti untuk dipelajari kemudian ditarik kesimpulannya (Sugiyono, 2012). Populasi dalam penelitian ini adalah 94 Pegawai Negeri Sipil (PNS). Sampel adalah bagian 
Putu Yogi Agastya Pratama, Pengaruh Konflik Interpersonal dan Beban Kerja terhadap...

dari jumlah dan karakteristik yang dimiliki oleh populasi tersebut, bila populasi besar dan peneliti tidak mungkin mempelajari semua yang ada pada populasi, karena keterbatasan dana, tenaga kerja dan waktu maka peneliti menggunakan sampel yang diambil dari populasi itu (Sugiyono, 2012:178). Sampel yang digunakan dalam penleitian ini menggunakan teknik sampel jenuh, karena populasi kurang dari jumlah 100 orang. Secara rinci sampel dalam penelitian ini disajikan pada Tabel 2.

Tabel 2.

Jumlah Pegawai PNS Dinas Perhubungan Provinsi Bali tahun 2016-2017

\begin{tabular}{cc}
\hline Bidang-Bidang DISHUB & Jumlah \\
\hline Kepala Dinas & 1 \\
Sekretariat Kepegawaian & 23 \\
Bidang Angkutan Jalan & 9 \\
Bidang Lalu Lintas & 13 \\
Bidang Pelayaran & 10 \\
Bidang Keterpaduan Moda & 8 \\
UPT. Perlengkapan Jalan & 8 \\
UPT. Trans Sarbagita & 10 \\
UPT. Pusdal LLAJ & 11 \\
Fungsional & 1 \\
\hline Total & 94 orang \\
\hline
\end{tabular}

Sumber : Dinas Perhubungan Provinsi bali 2016-2017

Teknik analisis data yang digunakan dalam penelitian ini adalah metode analisis regresi linear berganda. Rumusan model kerangka konseptual penelitian yang di pakai adalah sebagai berikut :

$$
\hat{Y}=\alpha+b_{1} X_{1}+b_{2} X_{2}+\mu
$$




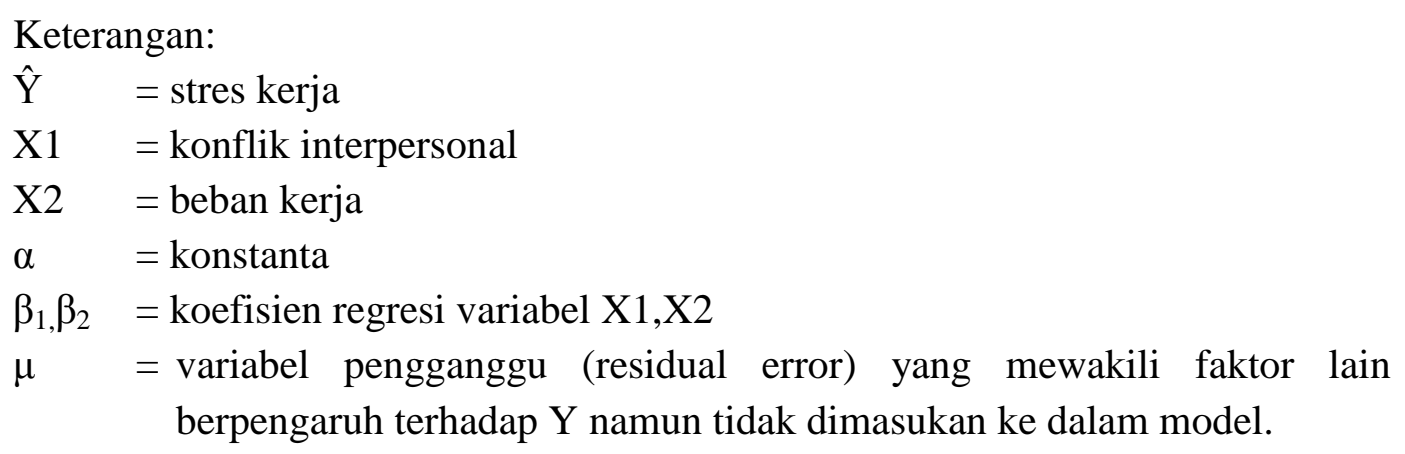

\section{HASIL DAN PEMBAHASAN}

Sebelum dilakukan uji analisis regresi, dilakukan pengujian instrumen penelitian terlebih dahulu dengan uji validitas dan uji reliabilitas. Suatu instrument dikatakan valid jika korelasi antara skor faktor dengan skor total bernilai positif dan nilainya lebih dari 0,30 ( $\mathrm{r}>0,3)$. Hasil uji validitas menunjukkan bahwa seluruh variabel memiliki nilai koefisien korelasi dengan skor total seluruh item pernyataan lebih besar dari 0,30 . Hal ini menunjukkan bahwa butir-butir pernyataan dalam instrument penelitian tersebut valid, sehingga dapat digunakan untuk melakukan penelitian. Selanjutnya suatu instrument dikatakan reliabel, jika instrument tersebut memiliki nilai Alpha Cronbach lebih dari 0,60. Hasil uji reliabilitas menunjukkan bahwa seluruh instrumen penelitian memiliki koefisien Cronbach's Alpha lebih dari 0,60. Hal ini dapat dikatakan bahwa semua instrumen reliabel sehingga dapat digunakan untuk melakukan penelitian.

Berdasarkan hasil penelitian dari penyebaran kuesioner karakteristik responden dijelaskan secara umum dapat dilihat dari jenis kelamin, usia dan tingkat pendidikan dengan jumlah responden sebanyak 94 orang. 
Tabel 3.

Karakteristik Responden

\begin{tabular}{|c|c|c|c|c|}
\hline No. & Variabel & Klasifikasi & Jumlah (orang) & Persentase \\
\hline \multirow{2}{*}{1} & \multirow{2}{*}{ Jenis Kelamin } & Laki - laki & 62 & 65,9 \\
\hline & & Perempuan & 32 & 34,1 \\
\hline \multicolumn{3}{|c|}{ Jumlah } & 94 & 100 \\
\hline \multirow[t]{3}{*}{2} & \multirow{3}{*}{ Usia } & $20-30$ & 48 & 51,1 \\
\hline & & $31-40$ & 25 & 26,6 \\
\hline & & $41-50$ & 21 & 22,3 \\
\hline \multicolumn{3}{|c|}{ Jumlah } & 94 & 100 \\
\hline \multirow{4}{*}{3} & \multirow{4}{*}{ Tingkat Pendidikan } & SMA & 22 & 23,5 \\
\hline & & SMK & 18 & 19,1 \\
\hline & & Diploma & 11 & 11,7 \\
\hline & & S1 & 43 & 45,7 \\
\hline \multicolumn{3}{|c|}{ Jumlah } & 94 & 100 \\
\hline
\end{tabular}

Sumber: Data primer diolah, 2017

Pada Tabel 3 menunjukkan tiga karakteristik dari responden yang terdiri dari jenis kelamin, usia dan tingkat pendidikan. Responden pada penelitian menunjukkan bahwa jenis kelamin laki-laki berjumlah 62 orang atau sebesar 65,9 persen. Sedangkan jenis kelamin perempuan berjumlah 32 orang atau sebesar 34,1 persen. Usia dalam responden penelitian ini mulai dari 20-30 tahun sebanyak 48 orang atau sebesar 51,1 persen, kemudian usia dari 31-40 tahun sebanyak 25 orang atau sebesar 26,6 persen dan usia 41-50 tahun sebanyak 21 orang atau sebesar 22,3 persen.

Tingkat pendidikan jumlah tertinggi terletak pada tingkat pendidikan SMK yang memiliki jumlah 18 orang atau sebesar 19,1 persen, sedangkan yang terendah pada tingkat pendidikan SMA yang memiliki jumlah 22 orang atau sebesar 23,5 persen dan tingkat pendidikan Diploma yang memiliki jumlah 11 orang atau sebesar 11,7 persen, kemudian tingkat pendidikan S1 yang memiliki jumlah 43 orang atau sebesar 45,7 persen. 
Penilaian responden tentang kepuasan kerja yang diukur dengan 5 item pertanyaan dapat disajikan pada Tabel 4. sebagai berikut :

Tabel 4.

Jawaban Responden Tentang Stres Kerja

\begin{tabular}{|c|c|c|c|c|c|c|c|c|}
\hline \multirow{2}{*}{ No } & \multirow{2}{*}{ Pernyataan } & \multicolumn{5}{|c|}{ Frekuensi Jawaban Responden } & \multirow[t]{2}{*}{$\begin{array}{l}\text { Rata- } \\
\text { Rata }\end{array}$} & \multirow{2}{*}{ Kriteria } \\
\hline & & STS & TS & $\mathrm{N}$ & S & SS & & \\
\hline 1 & $\begin{array}{l}\text { Stres kerja membuat tidak } \\
\text { mampu menyelesaikan } \\
\text { pekerjaan tepat waktu. }\end{array}$ & 17 & 33 & 14 & 18 & 12 & 2,73 & Baik \\
\hline 2 & $\begin{array}{l}\text { Stres kerja membuat tekanan } \\
\text { dan peraturan dalam } \\
\text { menjalankan tugas. }\end{array}$ & 17 & 32 & 24 & 13 & 8 & 2,61 & Baik \\
\hline 3 & $\begin{array}{l}\text { Stres kerja membuat hubungan } \\
\text { dengan rekan kerja tidak } \\
\text { harmonis. }\end{array}$ & 27 & 21 & 17 & 17 & 12 & 2,64 & Baik \\
\hline 4 & $\begin{array}{l}\text { Stres Kerja membuat kurang } \\
\text { jelas dengan informasi dari } \\
\text { perusahaan mengenai } \\
\text { pekerjaan. }\end{array}$ & 17 & 22 & 30 & 14 & 11 & 2,79 & Baik \\
\hline 5 & $\begin{array}{l}\text { Atasan tidak memberi tahu } \\
\text { tugas yang harus saya kerjakan. }\end{array}$ & 18 & 27 & 26 & 15 & 8 & 2,66 & Baik \\
\hline \multicolumn{7}{|c|}{ Rata-rata } & 2,69 & Baik \\
\hline
\end{tabular}

Sumber: Data primer diolah, 2017

Tabel 4. menunjukkan rata-rata dari 5 pertanyaan responden mengenai Stres kerja yaitu sebesar 2,69 yang berarti stres kerja yang dirasakan karyawan dinas perhubungan tergolong dalam kriteria baik. Indikator yang mempunyai rata-rata skor tertinggi ditunjukkan pada pernyataan "Stres kerja membuat kurang jelas dengan informasi dari perusahaan mengenai pekerjaan" dengan nilai rata-rata yaitu sebesar 2,79. Indikator yang mempunyai rata-rata skor paling rendah dibandingkan dengan rata-rata skor keseluruhan ditunjukkan pada pernyataan "Stres kerja membuat tekanandan peraturan dalam menjalankan tugas" dengan nilai rata-rata yaitu sebesar 2,61. 
Putu Yogi Agastya Pratama, Pengaruh Konflik Interpersonal dan Beban Kerja terhadap...

Penilaian responden tentang konflik interpersonal yang diukur dengan 5 item pertanyaan dapat disajikan pada Tabel 5.

Tabel 5.

Jawaban Responden Tentang Konflik Interpersonal

\begin{tabular}{|c|c|c|c|c|c|c|c|c|}
\hline \multirow{2}{*}{ No } & \multirow{2}{*}{ Pernyataan } & \multicolumn{5}{|c|}{ Frekuensi Jawaban Responden } & \multirow{2}{*}{$\begin{array}{l}\text { Rata- } \\
\text { Rata }\end{array}$} & \multirow{2}{*}{ Kriteria } \\
\hline & & STS & TS & $\mathrm{N}$ & $\mathrm{S}$ & SS & & \\
\hline 1 & $\begin{array}{l}\text { Konflik yang berbeda pendapat } \\
\text { dengan rekan kerja dalam } \\
\text { menyelesaikan pekerjaan }\end{array}$ & 13 & 38 & 23 & 17 & 3 & 2,56 & Baik \\
\hline 2 & $\begin{array}{l}\text { Konflik yang membuat } \\
\text { kesulitan dalam menyatukan } \\
\text { pikiran dengan rekan kerja } \\
\text { yang berbeda budaya dan } \\
\text { organisasi }\end{array}$ & 23 & 30 & 14 & 18 & 9 & 2,57 & Baik \\
\hline 3 & $\begin{array}{l}\text { Saya kerap kali menghindari } \\
\text { konflik yang terjadi terkait } \\
\text { dengan perbedaan kepentingan } \\
\text { antar pegawai }\end{array}$ & 0 & 3 & 28 & 38 & 25 & 3,90 & Baik \\
\hline 4 & $\begin{array}{l}\text { Saya merasa kecewa apabila } \\
\text { terjadi konflik antar pegawai }\end{array}$ & 15 & 31 & 17 & 21 & 10 & 2,79 & Baik \\
\hline 5 & $\begin{array}{l}\text { Saya merasa bersalah apabila } \\
\text { mengalami konflik }\end{array}$ & 3 & 9 & 22 & 37 & 23 & 3,72 & Baik \\
\hline & Rata- & & & & & & 3,11 & Baik \\
\hline
\end{tabular}

Tabel 5. menunjukkan rata-rata dari 5 pertanyaan responden mengenai konflik interpersonal yaitu sebesar 3,11yang berarti konflik interpersonal yang dirasakan karyawan Dinas perhubungan tergolong dalam kriteria baik. Indikator yang mempunyai rata-rata skor tertinggi ditunjukkan pada pernyataan "Saya kerap kali menghindari konflik yang terjadi terkait dengan perbedaan kepentingan antar pegawai" dengan nilai rata-rata yaitu sebesar 3,90. Indikator yang mempunyai rata-rata skor paling rendah dibandingkan dengan rata-rata skor keseluruhan ditunjukkan pada pernyataan "Konflik yang berbeda pendapat dengan rekan kerja dalam menyelesaikan pekerjaan" dengan nilai rata-rata yaitu sebesar 2,56. 
Penilaian responden tentang beban kerja diukur dengan 5 item pertanyaan dapat disajikan pada Tabel 6.

Tabel 6.

Jawaban Responden Tentang Beban Kerja

\begin{tabular}{|c|c|c|c|c|c|c|c|c|}
\hline \multirow{2}{*}{ No } & \multirow{2}{*}{ Pernyataan } & \multicolumn{5}{|c|}{ Frekuensi Jawaban Responden } & \multirow{2}{*}{$\begin{array}{l}\text { Rata- } \\
\text { Rata }\end{array}$} & \multirow{2}{*}{ Kriteria } \\
\hline & & STS & TS & $\mathrm{N}$ & S & SS & & \\
\hline 1 & $\begin{array}{l}\text { Beban kerja pegawai saat ini } \\
\text { sudah cukup untuk menangani } \\
\text { pekerjaan yang ada }\end{array}$ & 18 & 26 & 18 & 22 & 10 & 2,79 & Baik \\
\hline 2 & $\begin{array}{l}\text { Beban kerja yang saya capai } \\
\text { dalam pekerjaan sudah jelas }\end{array}$ & 18 & 29 & 16 & 20 & 11 & 2,76 & Baik \\
\hline 3 & $\begin{array}{l}\text { Saya selalu mengerjakan } \\
\text { pekerjaan yang sama setiap hari }\end{array}$ & 0 & 4 & 33 & 33 & 24 & 3,82 & Baik \\
\hline 4 & $\begin{array}{l}\text { Saya harus menyelesaikan } \\
\text { pekerjaan untuk mengurangi } \\
\text { beban kerja }\end{array}$ & 0 & 3 & 23 & 39 & 29 & 4,00 & Baik \\
\hline 5 & $\begin{array}{l}\text { Beban kerja saya sehari-hari } \\
\text { sudah sesuai dengan standar } \\
\text { pekerjaan saya }\end{array}$ & 13 & 34 & 23 & 19 & 5 & 2,67 & Baik \\
\hline \multicolumn{7}{|c|}{ Rata-rata } & 3,21 & Baik \\
\hline
\end{tabular}

Sumber: Data primer diolah, 2017

Tabel 6. menunjukkan rata-rata skor dari 5 pernyataan responden mengenai beban kerja sebesar 3,21 yang berarti beban kerja yang dirasakan karyawan Dinas perhubungan tergolong dalam kriteria baik. Indikator yang mempunyai rata-rata skor tertinggi ditunjukkan pada pernyataan "Saya harus menyelesaikan pekerjaan untuk mengurangi beban kerja" dengan nilai rata-rata yaitu sebesar 4.00. Indikator yang mempunyai rata-rata skor yang paling rendah dibandingkan dengan rata-rata skor keseluruhan ditunjukkan pada pernyataan "Beban kerja saya sehari-hari sudah sesuai dengan standar pekerjaan saya" dengan nilai rata-rata yaitu sebesar 2,67 .

Pengujian data dalam penelitian ini menggunakan teknik analisis regresi linier berganda. Tahapan melakukan teknik analisis regresi linier berganda yaitu : 
Tabel 7.

Hasil Analisis Regresi Linier Berganda

\begin{tabular}{|c|c|c|c|c|c|c|}
\hline \multirow{2}{*}{\multicolumn{2}{|c|}{ Model }} & \multicolumn{2}{|c|}{$\begin{array}{l}\text { Unstandardized } \\
\text { Coefficients }\end{array}$} & \multirow{2}{*}{$\begin{array}{c}\text { Standardized } \\
\text { Coefficients }\end{array}$} & \multirow{3}{*}{$\frac{\mathbf{T}}{-4.548}$} & \multirow{3}{*}{$\begin{array}{l}\text { Sig. } \\
.000\end{array}$} \\
\hline & & B & Std. Error & & & \\
\hline \multirow[t]{3}{*}{1} & (Constant) & -5.892 & 1.295 & & & \\
\hline & Konflik Interpersonal & .728 & .124 & .510 & 5.891 & .000 \\
\hline & Beban Kerja & .561 & .129 & .378 & 4.361 & .000 \\
\hline & R Square & & & & & 0,686 \\
\hline & Adjusted R Square & & & & & 0,679 \\
\hline & F Statistik & & & & & 99,434 \\
\hline & Signifikansi & & & & & 0,000 \\
\hline
\end{tabular}

\section{Pengaruh konflik interpersonal terhadap stres kerja}

Hasil penelitian ini menyatakan bahwa terdapat pengaruh positif konflik interpersonal terhadap stres kerja pada kantor Dinas Perhubungan Provinsi Bali. Hal ini dikarenakan adanya kurangnya komunikasi antara pegawai melaksanakan tugas yang diberikan dan adanya perbedaan karena unsur pemikiran dan budaya yang berbeda antara pegawai mengakibatkan konflik interpersonal berpengaruh positif dan signifikan terhadap stres kerja pada kantor Dinas Perhubungan Provinsi bali.

Hasil ini mengembangkan peneliti yang dilakukan oleh Videmsel et al. (dalam Stafylal et al., 2013) mengenai 85 manajer di Slovenia yang menyatakan bahwa manajer perempuan memiliki tingkat stres yang lebih tinggi dan gejala kecemasan yang lebih parah dibandingkan laki-laki terkait dengan konflik interpersonal. Selain itu, hasil penelitian yang dilakukan oleh (Agagiotou, 2011) Mengenai 400 orang guru di Pakistan, yang menemukan bahwa adanya hubungan positif dan signifikanantara variabel konflik interpersonal terhadap stres kerja. Hal yang serupa dikemukakan oleh (Stafylal et al., 2013) dalam penelitian mengenai 
271 orang dewasa di Yunani menunjukan bahwa adanya hubungan positif dan signifikan variabel konflik interpersonal terhadap stres kerja.

\section{Pengaruh beban kerja terhadap stres kerja}

Pengaruh beban kerja terhadap stres kerja mendapatkan hasil positif dan signifikan pada kantor Dinas perhubungan Provinsi Bali. Hal ini disebabkan karena adanya meningkatnya beban kerja yang diiringi dengan kurangnya waktu dalam mengerjakan pekerjaan serta kurangnya kesempatan untuk bisa mengambil keputusan dalam bekerja mengakibatkan meningkatnya stres kerja di kantor Dinas Perhubungan Provinsi Bali.

Hasil penelitian ini mengembangkan hasil penelitian yang dilakukan oleh Haryanti dan Purwaningsih (2013) terhadap pesawat instalasi unut gawat darurat di RSUD kabupaten Semarang, yang menunjukan bahwa hubungan antara beban kerja dengan stres kerja memiliki hubungan positif dan signifikan. Hal ini bisa diartikan, semakin meningkat beban kerja semakin menyebabkan stres. Hasil penelitian ini juga mengembangkan hasil penelitian yang dilakukan Mahwidi (2010), tentang pengaruh beban kerja terhadap stres kerja yang mendapatkan hasil positif dan signifikan pada perawat di RSU yang didapatkan hasil bahwa terdapat pengaruh positif dan signifikan beban kerja fisik (subyektif) dan beban kerja mental (subyektif) terhadap stres kerja.

\section{SIMPULAN}

Simpulan yang dapat diambil berdasarkan hasil analisis dan pembahasan adalah Konflik Interpersonal berpengaruh positif dan signifikan terhadap Stres 
Putu Yogi Agastya Pratama, Pengaruh Konflik Interpersonal dan Beban Kerja terhadap...

Kerja di Dinas Perhubungan Provinsi Bali. Hal ini menunjukan bahwa semakin tinggi konflik interpersonal, maka semakin tinggi pula perilaku peran stress kerja yang ada di Dinas Perhubungan Provinsi Bali. Kedua, beban kerja berpengaruh positif dan signifikan terhadap stres kerja di Dinas Perhubungan Provinsi Bali. Hal ini menunjukkan bahwa semakin tinggi beban kerja mereka maka semakin tinggi pula perilaku peran Stres Kerjadi Dinas Perhubungan Provinsi Bali.

Berdasarkan hasil analisis penelitian, pembahasan dan kesimpulan terdapat beberapa saran yang dapat dipergunakan sebagai bahan pertimbangan dalam menentukan kebijakan dimasa mendatang terutama yang berkaitan dengan konflik interpersonal, beban kerja dan stress kerja, antara lain: stress kerja dapat dikurangi dengan lebih memperhatikan beban kerja dibandingkan konflik interpersonal. Hal ini dikarenakan beban kerja yang berlebih yang diberikan kepada karyawan yang akan lebih meningkatkan stress kerja dibandingan kondlik interpersonal itu sendiri. Selain itu, konflik interpersonal dapat dikurangi dengan cara setiap kepala bagian dari kantor Dinas Perhubungan Provinsi Bali harus memeberikan perhatian yang lebih perbedaan pendapan antar individu dan perbedaan pemikiran karena latar belakang kebudayaan yang berbeda. Hal inilah yang akan meningkatkan stress kerja yang bersumber dari konflik interpersonal dan beban kerja

\section{REFERENSI}

Agagiotou, S. 2011. The Work stress of social workers and the relationship with work engagement and emotional intelligence. Graduate thesis. University of Macedonia Economic and Social Sciences. Department of Educational and Social Policy, Thessaloniki (in Greek). 
Ahari, M., D. J. Mehrabi., K. Kord., and D. F. Karimi. 2013. Studying the Relationship of job stress with job Satisfaction and Organizational Productivity among the telecommunications employees in lorestan. Interdisciplinary journal of Contemporary Research in business, Vol 5.

Almasitoh, U. H. 2011. Stres Kerja Ditinjau dari Konflik Peran Ganda dan Dukungan Sosial pada Perawat. Jurnal Psikologi Islam Universitas Widya Dharma Klaten, 8(1), 63-82.

Atmaji, L. 2011. Pengaruh Stres Kerja dan Kepuasan Kerja terhadaKinerja Perawat Studi pada Rumah Sakit Islam sultan Agung Semarang. Skripsi. Fakultas Ekonomi Universitas Diponegoro Semarang.

Arnold, J., J. Silvester., F. Peterson., I. Robertson., C. Cooper., and B. N. Burnes. 2005. Work psychology: Understanding human behavior in the work place (4th ed.), Essex: Pearson Education Limited.

Berkbigler, E., and E. D. Kevin. 2014. Required Scripting and Work Stress in the Call Center Environment: A Preliminary Exploration. Southeast Missori State University, pp : 233-255.

Caplan, R. D. 1980. Job demands and worker health: Main effects and occupational differences, Ann Arbor, MI: Survey Research Center, Institute for Social Research, University of Michigan.

Dana, D. 2006. Resolusi konflik : alat bantu mediasi untuk kehidupan kerja seharihari. Jakarta : PT Bhuana Ilmu Populer

Dewi, T. H., dan A. Handayani. 2013. Kemampuan Mengelola Konflik Interpersonal di Tempat Kerja Ditinjau dari Persepsi terhadap Komunikasi Interpersonal dan Tipe Kepribadian Ekstrovert. Jurnal Psikologi Undip, 12(1), 34-43.

Dhania, D. R. 2010. Pengaruh Stres Kerja, Beban Kerja Terhadap Kepuasan Kerja: studi pada Medical Representatif di kota Kudus. Jurnal Psikoloogi Universitas Muna Kudus, Vol.1, PP : 15-23.

Dijkstraa, M., C. Dreub., A. Evers., and D. V. Dierendonck. 2009. Passive responses to interpersonal conflict at work amplify employee strain. European Journal of Work and Organizational Psychology, 18(4), 504423. 
Putu Yogi Agastya Pratama, Pengaruh Konflik Interpersonal dan Beban Kerja terhadap...

Dwijanti, J. E. 2000. Perbedaan pengguna metode resolusi konflik pemutusan hubungan kerja (PHK) antara manajemen dan karyawan. Anima. Indonesia Psychological Journal.

Fah, C. B., S. Y. Foon., C. Leong., dan S. Osman. 2010. An Exploratory Study on Turnover Intention among Private Sector Employees. International journal of business and management, 5(8), 57-64.

Ghozali, Imam. 2011. Aplikasi Analisis Multivariate dengan Program IBM SPSS 19. Semarang: Badan Penerbit Universitas Diponogoro.

Gunov, S., M. Gerald., F. Gregory., and D. Allen. 2011. Use of the Roboflag Sythetic Task Evironment to the Vestigate Workload and Stress Respons in UAV Operation. Psychonomic Society, pp: 771-781.

Handoko. T. T. 2001. Manajemen Personalia Dan Sumber Daya Manusia. Edisi kedua, Yogyakarta: Andi.

Hariyono, W., D. Suryani., dan Y. Wulandari. 2009. Hubungan antara Beban Kerja, Stres Kerja dan Tingkat Konflik dengan Kelemahan Kerja Perawat di Rumah Sakit Islam Yogyakarta P DHI Kota Yogyakarta. Fakultas Kesehatan Masyarakat, Universitas Ahmad Dahlan, 3(3), 162-232.

Haryanti, F. A., dan P. Purwaningsih. 2013. Hubungan antara Beban Kerja dengan Stres Kerja Perawat di Instalasi Gawat Darurat RSUD Kabupaten Semarang. Jurnal Manajemen Keperawatan, 1(1), 48-56.

Hung, K. P., dan C. K. Ling. 2013. When Communication Effective for Reducing Interpersonal Conflict? The Moderating Effect of Credibility and Benevolence. Department of Business Administration, Ming Chuan University, pp: 141-152.

Ilies. R., M. Johnson., T. Judge., and J. Keeney. 2011. A within-individual study of interpersonal conflict as a work stressor: Dispositional and situational moderators. Journal of Organizational Behavior, 32(1), 44-64.

Kahn. R. L. and R. P. Quinn. (1970). Role stress:A frame work for analysis. In a mclean (ed) Mental Healthhand Work Organization. Chiocago: Rand McNally, 50-155.

Leila, G. 2002. Stres dan Kepuasan Kerja. Fakultas Kedokteran Program Studi Psikologi Universitas Sumatera Utara, PP: 1-13.

Lexshimi, R., S. Tahir., L. P. Santhna., and M. D. Nizam. (2007). Prevalence of Stress and Coping Mechanism among Staff Nurses in the Intensive Care Unit, 2(2), 146-153. 
Luthan, Fred. 2006. Prilaku Organisasi. Yogjakarta : Andi.

Mahwidhi. 2010. Hubungan antara stres kerja dengan gangguan kesehatan perawat di IRD RSVP DR. Jurnal Ekonomi. Soeradji Tirtonegoro Klaten.

Munandar, A. S. 2001. Psikologi industri dan organisasi. Edisi 1. Jakarta : UI Press.

Noviansyah, Z. 2011. Pengaruh Stres Kerja dan Motivasi Kerja Terhadap Kinerja Karyawan PT. Perkebunan Minanga Organ Baturaja. Jurnal Manajemen dan Bisnis Sriwijaya, Vol.9, PP 45-58.

Mnurung, T. M., dan I. Ratnawati. 2012. Analisis Pengaruh Stres Kerja dan Kepuasan Kerja Terhadap Turnover Intention Keryawan (Studi Pada Stikes Widya Husada Semarang). Diponegoro Journal Of Management, 1(2), 145-157.

Puzideastuti, K. 2004. Kemampuan mengelola konflik interpersonal di tempat kerja ditinjau dari kecenderungan ekstraversi pada karyawan. Skripsi. (tidak diterbitkan). Semarang. Fakultas Psikologi Universitas Katolik Soegijapranata.

Paille, P. 2011. Stressful Work, Citizenship Behaviour and Intention to Leave the Organization in a high Turnover Environment: Examining the Mwdiating Role of the Job Sattisfaction. Journal of Management Research, 3(1).

Qureshi, M. I. 2013. Relationship Between Job Stress, Workload, Environment and Employees Turnover Intention: What We Know, What Shoundl We Know. World Applied Sciences Journal, 23(6), 32-49.

Restiaty. 2006. Hubungan tentang beban kerja dengan kelelahan kerjadi RS Surabaya. Skripsi.

Robbins, Stephen. 2008. Perilaku Organisasi. Jakarta : Salemba Empat.

Rivai, Veithzal. 2008. Manajemen Sumber Daya Manusia untuk Perusahaan, dari Teori ke Praktik, Jakarta: PT Rajagrafindo Persada.

Sliter, M. T., S. Y. Pui., K. A. Sliter., and S. M. Lex. 2011. The differential effects of interpersonal conflict from customers and coworkers: Trait anger as a moderator. Journal of Occupational Health Psychology, 16(4), 424-440.

Stafyla, A., G. Kaltsidou dan N. Spyridis. 2013. Gender Differences in work Stress, Related to Organizational Conflict and Organizational Constrains : 
Putu Yogi Agastya Pratama, Pengaruh Konflik Interpersonal dan Beban Kerja terhadap...

An Empirical Research. International Journal of Economic Science and Applied Research, 6(1), 91-101.

Sugiyono. 2012. Metode Penelitian Bisnis. Bandung : Alfabeta.

Supardi dan S. Anwar. 2011. Dasar - dasar Perilaku Organisasi. Yogyakarta: UII Press.

Suprihanto, J., A. M. Harsiwi., dan P. Hadi. 2003. Perilaku Organisasional. Yogyakarta. Sekolah Tinggi Ilmu Ekonomi. YKPN.

Suyana, U. M. 2007. Buku Ajar Aplikasi Analisis Kuantitatif. Denpasar. Fakultas Ekonomi Universitas Udayana.

Siagian, S. P. 2010. Manajemen sumber daya manusia. Jakarta: Bumi Aksara.

Sunyoto, D. 2012. Manajemen Sumber Daya Manusia. Cetakan 1. Yogyakarta: CAPS (Center for Academic Publishing Service).

Wijaya, H. C. 2014. Penerimaan Pasangan Suami Istri Terhadap Konflik Interpersonal dalam Film Fireproof. Jurnal E-Komunikasi. Universitas Kristen Petra Surabaya.

Winardi. 2004. Manajemen perilaku organisasi. Jakarta : Prenada Media.

Widodo, S. E. 2015. Manajemen Pengembangan Sumber Daya Manusia. Yogyakarta. Pustaka Pelajar. 